\title{
Análise de obras da literatura infantil como estratégia de formação do pedagogo/ professor: saber ler, saber escolher
}

\section{Analysis of childhood literature as a strategy in teacher training knowledge in reading, knowledge in choosing}

\author{
Elisa Maria Dalla-Bona* \\ Jair Tadeu da Fonseca**
}

\begin{abstract}
RESUMO
Estudo de caso na disciplina "Metodologia do ensino da literatura infantil", no curso de Pedagogia, da Universidade Federal do Paraná (Brasil). Predomina entre os estudantes a ideia utilitarista do trabalho escolar com a literatura infantil e seu uso como pretexto para ensinar os conteúdos escolares. Nas aulas, a partir de alguns princípios oriundos da teoria da estética da recepção e seus impactos para o ambiente escolar, são confrontadas obras consideradas de boa e de má qualidade. O artigo analisa cinco delas (Luanda enroladinha, Obax, Pra saber voar, O monstro monstruoso da caverna cavernosa, $O$ Grúfalo) e ressalta a efetividade da estratégia para desestabilizar os estudantes e os auxiliar a pensar sobre o papel da literatura infantil no ensino e na formação do jovem leitor.

Palavras-chave: Literatura Infantil. Estética da Recepção. Formação de Professores. Ensino Fundamental I. Pedagogia.
\end{abstract}

* Universidade Federal do Paraná. Setor de Educação. Programa de Pós-Graduação em Educação: Teoria e Prática de Ensino. Curitiba, Paraná, Brasil. E-mail: elisabona2@gmail.com. http://orcid.org/0000-0002-4320-1203.

** Universidade Federal de Santa Catarina. Departamento de Língua e Literatura Vernáculas do Centro de Comunicação e Expressão. Programa de Pós-Graduação em Literatura. Florianópolis, Santa Catarina, Brasil. E-mail: jairfons@gmail.com. https://orcid.org/0000-0003-4575-1118 


\begin{abstract}
A case study for childhood literature teaching methods offered to an undergraduate course of Pedagogy at Federal University of Paraná (Brazil). There is a prevailing perception amongst students of a utilitarian use of school assignments with childhood literature in teaching of several topics. Teachers confronted literature considered as "good" or "bad" by applying concepts of reception aesthetics and its influence in class. We analyze five such stories in Portuguese: Luanda enroladinha (Tangled Luanda), Obax (Obax), Pra saber voar (To know how to fly), O monstro monstruoso da caverna cavernosa (The monstrous monster from the cavernous cave), O Grúfalo (The Grufalo) and show the effectiveness of the strategy to destabilize students, as well as helping them to review the role of childhood literature in teaching and in training young readers.
\end{abstract}

Keywords: Childhood literature. Reception Aesthetics. Teacher Training. Elementary School. Pedagogy.

\title{
Introdução
}

Nos cursos de Pedagogia são formados os professores da educação infantil e dos anos iniciais do ensino fundamental, mas predomina a fragilidade desta formação no que se refere à capacidade dos professores em formar leitores. Esse problema se revela em nível macro, por exemplo, nos resultados pífios dos alunos brasileiros do $5 .^{\circ}$ ano que frequentam a rede pública de ensino. $\mathrm{Na}$ Prova Brasil 2015 apenas 50\% demonstrou competência mínima de leitura e interpretação de textos.

A formação do leitor na escola vai mal porque os alunos pouco têm acesso aos textos literários e quando lhes é dada essa chance são submetidos a um contato inadequado com esses textos em sala de aula, em virtude de diferentes fatores como: os alunos não têm liberdade de escolher o que gostariam de ler; não podem manusear as prateleiras das bibliotecas escolares; eles têm sérias limitações no domínio da alfabetização, dificuldades com a leitura autônoma e raramente os professores leem histórias para eles; predomina a preocupação dos professores em ensinar os conteúdos escolares e muito pouco em formar leitores, o que faz com que trabalhem na sala de aula com os textos "literários" (se é que podem ser chamados assim) com propósitos utilitários e não estéticos.

A formação do leitor não é questão nem suficientemente, nem adequadamente tratada nos cursos de Pedagogia. Cosson (2013) alerta para o fato de que são poucos os cursos de Pedagogia que oferecem uma disciplina da área de 
literatura e mais raros ainda são os que conciliam o literário com o pedagógico. Para o autor "sem uma formação específica de literatura, esse professor tende a reduzir o aspecto literário ao exercício da imaginação e da fantasia, quando não privilegia a oportunidade de através da obra introduzir algo que deseja ensinar a seus alunos.” (COSSON, 2013, p. 20). Converge nessa mesma direção o artigo "Literatura e formação do pedagogo: caminhos que (ainda) não se cruzam", de Saldanha e Amarilha (2016), no qual as autoras indicam a ausência da literatura nos cursos de Pedagogia em 27 universidades federais pesquisadas, o que fragiliza o conhecimento humanístico, essencial para a formação do professor.

Na Universidade Federal do Paraná, no curso de Pedagogia, é ofertada uma disciplina, que, embora bastante procurada pelos estudantes, não alcança a todos porque é optativa, intitulada "Metodologia do ensino da literatura infantil", com carga horária de 30 horas semestrais. A abordagem do conteúdo concilia as questões literárias (as especificidades da literatura infantil, seu histórico, características do texto literário para crianças, a sua função humanizadora) e pedagógicas (metodologia de abordagem do texto literário adequada para a formação do imaginário, do desenvolvimento da capacidade leitora e escritora da criança).

Mas um dos aspectos marcantes durante as aulas é o quanto está enraizada entre os estudantes a ideia de que o trabalho escolar com a literatura infantil tem que se prestar ao utilitarismo, ao uso da literatura como pretexto para ensinar os conteúdos escolares, que vão desde as noções das diferentes áreas do conhecimento (matemática, língua portuguesa, ciências) até a abordagem de vários temas como, por exemplo, o combate à intolerância, as questões étnico-raciais e o bullying.

O esforço empreendido na disciplina para romper com essa concepção e alicerçar novos paradigmas tem sido grande. Para este artigo, destacam-se aquelas aulas em que são analisadas obras da literatura infantil. A estratégia utilizada consiste em formar grupos de até quatro pessoas e solicitar que analisem duas obras. Propositalmente são entregues uma obra de boa qualidade literária e outra de qualidade questionável ou mesmo ruim. Mais adiante, analisam-se quatro obras (Obax, Pra saber voar, O monstro monstruoso da caverna cavernosa, $O$ Grúfalo) com potencial literário para divertir uma criança, auxiliá-la a compreender e refletir sobre o mundo e o ser humano, escolhidas também pelo seu valor estético.

Por ora, salienta-se que, de início, nem sempre os estudantes conseguem fazer uma crítica a histórias utilitaristas. Por exemplo, em contraste com a instigante história Obax, de tema africano, é analisada Luanda enroladinha, de Antonio Cesar Lins Rodrigues, ilustrada por Tadeu Costa. Nela, de maneira explícita, é introduzido o tema da africanidade. Questão evidente desde a es- 
colha do nome da protagonista, a formiga Luanda, até os ensinamentos de sua avó sobre Angola, o país de origem de seus ancestrais, passando pelas "aulas" sobre diversidade e a existência no mundo inteiro de formiguinhas pretinhas e lindas como Luanda. Assim, Luanda enroladinha afirma que já não se sente tão diferente como antes. Então, a avó aproveita para ensinar algo mais: "Todos somos diferentes e, ao mesmo tempo, iguais, pois temos os mesmos direitos, e as mesmas responsabilidades na sociedade" (p. 24), possibilitando a Luanda perguntar: "Isso também acontece com as pessoas e com os outros animais, não é, vovó?” (p. 24). O que se segue é a afirmação de que há pessoas altas, baixas, magras, gordas, negras e brancas, com as respectivas ilustrações de pessoas com essas características. O mesmo é apresentado com diferentes animais. Culmina com Luanda afirmando que está mais feliz por conhecer seu povo, ser diferente e se sentir igual.

Em suma, com a conclusão previsível e "edificante" da narrativa, confirma-se o que se pode constatar ao longo da trama: toda sua ênfase reside na "moral da história", em ensinar uma lição, mas, ao contrário do que veremos em outros livros analisados, sem empenho literário, ou seja, sem o criativo trabalho verbal necessário a um texto de literatura. Apesar de lançar mão do recurso clássico da fábula, o mesmo recurso das histórias a serem tratadas mais adiante, Luanda enroladinha empobrece sua mensagem por não criá-la a partir de recursos imaginativos e poéticos de linguagem, quando se constrói pela redundância, tanto por meio da óbvia relação entre texto e ilustração, como apontado, quanto por sempre reiterar algo e forçar sua confirmação textual, como em "Viram como eu sou linda?" (p. 3). Outro exemplo está no seguinte trecho: "Há duas coisas que Luanda adora e vive dizendo para todo mundo: o seu cabelo e a cor da sua pele"; seguindo-se abaixo, na mesma página, balões como os de quadrinhos, em que se têm a fala da protagonista, com dizeres como "meu cabelo é muuito bonitinho...", e "minha pele é pretiiiiiiiiiiiinha, pretinha" (p. 15). Nesses casos, a redundância se dá também pela imitação escrita da expressividade oral. Outro problema em relação ao livro é que, apesar de seu caráter supostamente didático, ele não alude à escravidão quando poderia fazê-lo no seguinte trecho: "- E elas [as formigas africanas] vieram fazer o quê [no Brasil]?; - As mais diversas atividades - respondeu a avó" (p. 20). Mesmo algo tão grave como o evento histórico omitido na resposta de Vovó Angola poderia receber tratamento literário condizente, caso a fábula fosse coerente com seu didatismo.

O envolvimento dos estudantes nessa atividade é intenso e, frequentemente, externam o quanto ficam desestruturados e provocados a repensar suas concepções sobre a formação do leitor, como pode-se constatar na avaliação de alguns deles realizada ao término da disciplina no $1 .^{\circ}$ semestre de 2017. 
A estratégia usada para analisar os livros foi fantástica. Não foi uma atividade induzida (dizendo qual era bom e qual era ruim). Nós lemos os livros e, com base no que tínhamos visto antes, sobre a literatura não ser didatizante, chegamos à conclusão de qual livro seria realmente literatura $e$, por essa razão, qual seria o mais indicado para uma criança.

Muito obrigada pelas aulas!

Foram fantásticas. (J.)

Através da análise de livros foi possível perceber visualmente muitas das teorias apresentadas em sala. (L.)

Eram apresentados livros "bons" e "ruins" de literatura infantil, ou seja, a professora levava tipos diferentes de livros para instigar a reflexão dos alunos, a partir do que já tinha sido abordado nas leituras no decorrer da disciplina, fazendo os alunos perceberem quais elementos eram positivos e negativos nas obras.

Obras com alguma atividade no final do livro, com conteúdo didático na história, com texto fraco e simplista e ilustrações que fogem da realidade ou não conversam com o texto, são alguns aspectos aprendidos para considerar um livro ruim. Já os livros bons, como aprendido, devem conter uma história interessante, com alguma intriga, suspense ou mesmo com várias possibilidades de interpretação, que provoque o leitor a pensar sobre o que o texto apresenta. As imagens devem complementar o texto e não deixar o leitor confuso, mas, sim, oferecer novos elementos que ajudem na construção pessoal que cada leitor dá à história. Por fim, um dos aspectos mais relevantes da disciplina foi o aprendizado de que as boas histórias não precisam ter um final feliz, mas sim levar os leitores a construirem novos caminhos e criarem novas possibilidades de interpretação, tornando as obras de literatura infantil mais próximas de si mesmos, ampliando o olhar e adquirindo o prazer pela leitura. (F.)

Acredito que a análise das literaturas boas e ruins seja fundamental nesse processo de ensino, pois nos ajuda a separar o joio do trigo e a levar as melhores obras para os alunos. (M.)

A disciplina me fez pensar como hoje nas escolas estão fazendo da leitura um momento raro e escolhendo péssimos livros, não deixando que a criança se deleite na leitura. (A.) 
Durante a atividade de análise dos livros, alguns grupos defendem que os dois livros analisados são muito bons porque por meio deles conseguiriam ensinar os conteúdos escolares. Na medida em que os grupos apresentam as suas críticas aos livros com pretextos didáticos e não literários, eles conseguem provocar uma conscientização dos que, inicialmente, não haviam percebido esse viés e, inclusive evocam a lembrança de que eles próprios quando crianças foram submetidos à abordagem utilitarista da literatura infantil e agora tomam essa experiência como modelo. Com o auxílio dos estudantes que já têm se posicionado mais criticamente sobre o uso da literatura infantil na escola, consegue-se ensiná-los a olhar, como no conto "A função da arte/l”, de Eduardo Galeano (2000, p. 15):

Diego não conhecia o mar. O pai, Santiago Kovadloff, levou-o para que descobrisse o mar. Viajaram para o Sul.

Ele, o mar, estava do outro lado das dunas altas, esperando.

Quando o menino e o pai enfim alcançaram aquelas alturas de areia, depois de muito caminhar, o mar estava na frente de seus olhos. E foi tanta a imensidão do mar, e tanto seu fulgor, que o menino ficou mudo de beleza. E quando finalmente conseguiu falar, tremendo, gaguejando, pediu ao pai: - Me ajuda a olhar!

Por meio dessa estratégia chega-se a desestabilizar os estudantes, auxiliá-los a pensar sobre o lugar e a função da literatura na escola e fora dela e a considerar a literatura como um meio tanto de "habilitar quanto de empoderar culturalmente o aluno" (COSSON, 2013, p. 21). Trata-se de um percurso para instrumentalizar o professor para trabalhar na formação de jovens leitores. Enfim, como nas palavras de Galeano: ajudá-los a olhar.

\section{A relação entre a análise de obras e a formação do pedagogo/professor}

Nas avaliações dos estudantes, acima apresentadas, eles asseveram que a análise dos livros ocorreu com base no que tinham estudado durante o semestre na disciplina "Metodologia do ensino da literatura infantil", um trabalho apoiado em alguns princípios oriundos da teoria da estética da recepção e seus impactos para o ambiente escolar. As conclusões a que chegaram não eram mera análise 
de um livro literário, mas levavam em consideração, além dos aspectos literários e estéticos da obra, também o seu potencial de interação com o jovem leitor.

O trabalho sobre a estética da recepção dos pensadores alemães da Escola de Constança desempenha papel de destaque no desenvolvimento de "uma teoria que reflete sobre o leitor a experiência estética, as possibilidades de interpretação e, paralelamente, suas repercussões no ensino e no meio [...]" (ZILBERMAN, 2004, p. 6). Nessa teoria, a literatura é concebida como uma forma de comunicação, o leitor é considerado como entidade coletiva a quem o texto se dirige e é o principal elo do processo literário, e a leitura é o ato resultante dessa troca de experiências estéticas.

A obra literária não é um mero reflexo das palavras do autor reproduzidas na mente do leitor, mas o resultado de uma interação ao mesmo tempo receptiva e criadora e profundamente dependente da mediação da escola para auxiliar o leitor a preencher as lacunas deixadas pelo autor, para auxiliá-lo a entrar no jogo do texto, a mergulhar no mundo da imaginação e da ficção, a dominar a linguagem literária para reconstruir o universo simbólico contido nas palavras.

Tratando-se do texto literário, a estética da recepção reforça que a fruição se dá pela experiência estética provocada pelo contato com uma obra de arte. O professor deve ser um auxiliar do aluno para aproximá-lo do maior número possível de obras, de modo a ampliar seu universo cultural, instigá-lo a desvendar as pistas deixadas pelo autor e a expressar os conteúdos intelectuais, sensoriais e afetivos despertados pela obra.

Ao professor cabe aproximar os alunos de obras que superem as suas expectativas, os instiguem, os desafiem e, para usar um termo de Jauss (1993, 2002), os emancipem, além de proporcionar ao leitor a participação na escolha do que vai ler e na definição dos rumos da construção do conhecimento, de forma que efetivamente participe e se comprometa com o processo de aprendizagem.

Mesmo na fase de formação do leitor, o professor precisa considerar que "ler é imergir num universo imaginário, gratuito, mas organizado, carregado de pistas as quais o leitor vai assumir o compromisso de seguir, se quiser levar sua leitura, isto é, seu jogo literário a termo" (BORDINI; AGUIAR, 1993, p. 27). Portanto, ler literatura na escola é se inserir num mundo lúdico, prazeroso, divertido e emocionante, provocado por ações pedagógicas estruturadas, organizadas e planejadas, sem serem sisudas e impositivas, mas desencadeadoras da interação do leitor com o texto.

A escola precisa criar as condições para que se estabeleça uma efetiva comunicação do leitor com o texto, mobilizando seu imaginário de forma que interfira criadoramente no texto. Conforme a estética da recepção, a literatura não se esgota no texto: completa-se no ato de leitura, ou na recepção do texto pelo leitor, num processo sempre ativo, pois o leitor, "ao defrontar-se com o 
texto, traz consigo toda sua bagagem de experiências linguísticas e sociais, que deve mobilizar a partir das provocações e lacunas que a obra lhe propõe" (BORDINI; AGUIAR, 1993, p. 86).

Ao ser colocado em contato com obras literárias desafiadoras, no ambiente escolar, é exigido do leitor um esforço salutar para responder aos desafios ante o novo, para "adotar uma postura de disponibilidade, permitindo à obra que atue sobre seu esquema de expectativas através das estratégias textuais intencionadas para a veiculação de novas convenções" (BORDINI; AGUIAR, 1993, p. 84). Uma ação pedagógica com essas características provocativas, problematizadoras e reflexivas provoca impactos no leitor (aluno) e em seu meio social (escolar e familiar), na medida em que, por meio da leitura literária, provoca a revisão de suas crenças, atitudes e valores.

Frequentemente alguns estudantes matriculados na disciplina "Metodologia de Ensino da Literatura Infantil" solicitam listas de livros para eles adquirirem ou para a escola em que trabalham, alguns inclusive delimitam a faixa etária dos seus alunos para não haver "dúvida" nas indicações. Aos poucos vão compreendendo o asseverado por Hunt (2010, p. 29), de que essas listas "restringem e impedem o raciocínio". O que se pretende é, além de colocá-los diante do mar (livros), ajudá-los a aprender a olhar, como o jovem Diego do texto de Galeano, ou nas palavras de Hunt (2010, p. 29) “o que precisamos é de um modo de abordar a literatura infantil que nos ajude a fazer escolhas criteriosas a partir de princípios básicos".

Para as análises das obras na disciplina são considerados os desafios do professor dos alunos pequenos, nas palavras de Cosson (2013, p. 20):

[...] o professor de literatura das séries iniciais do Ensino Fundamental e da educação infantil enfrenta o dilema de conciliar o literário com o pedagógico, sem deixar de observar questões de ordens tão distintas quanto o material de confecção da obra; o formato favorável ao seu manuseio; a fonte empregada na impressão; a inteligibilidade sintática e lexical do texto; a elaboração imagética das ilustrações em termos de cores e formas, e outros tantos elementos em um mar de publicações.

Aguiar (1999) auxilia-nos a complementar o que lemos na citação de Cosson sobre a importância de também se considerar os aspectos relativos à materialidade das obras, da ilustração e do texto. 
Como estamos considerando a obra literária enquanto fenômeno com leis internas de funcionamento e objeto à mercê das regras sociais de uso, devemos nos ater a seu invólucro e trânsito entre os leitores. Aqui, avulta a questão da ilustraçãoe, mais genericamente, da edição. O livro é o texto e também sua formação material, com uma face física que se apresenta ao leitor e lhe aponta sentidos. Por isso, cada vez mais, numa sociedade sedutora como a nossa, a confecção do livro infantil tem merecido cuidados visuais: capa, diagramação, ilustração.

No entanto, esses elementos, mais do que um caráter apelativo de conquista do consumidor, são signos construtores de significações. Importa, então, que eles não sejam apenas redundâncias do texto escrito, repetindo as informações ali contidas (quando não contrariadas), mas também índices novos, que se somam à constituição do sentido global do livro: ilustrações criativas, em que jogos de cores, de luz e sombra, de detalhes e superposições permitam novas interpretações; diagramaçâo cuidadosa e original, que oriente o leitor em direção de novos sentidos; capas sugestivas que provoquem curiosidade, etc. Nossa proposta é a de que a multiplicidade de linguagens de que se faz o objeto livro permita a emergência de ditos, não ditos e subentendidos, verbais e visuais, como possibilidades de sentidos que se colocam ao leitor. Dentre elas, ele vai exercer sua liberdade de escolha, combinando dados segundo sua percepção e dando um nexo para sua leitura. (AGUIAR, 1999, p. 246-247).

Assim, aos estudantes, durante a realização da disciplina, são criadas as condições para que aprendam a distinguir as obras que se destacam pela qualidade dos seus componentes externos (capa, diagramação, ilustração), internos (espaços vazios a serem preenchidos pela reflexão do leitor) e pela sua capacidade emancipatória (desafiar o leitor, criar expectativas, surpreendê-lo, despertar a fruição).

Em síntese, o objetivo da disciplina "Metodologia de Ensino da Literatura Infantil" é proporcionar aos estudantes de Pedagogia o desenvolvimento da sua capacidade de provocar na escola o encontro da literatura infantil com o seu leitor.

\section{Saber ler, saber escolher}

A proposta de trabalho da disciplina é sensibilizar o pedagogo/professor para reconhecer nas obras da literatura infantil o sugerido pela teoria da estética 
da recepção, que alerta sobre a polissemia, os vazios, os espaços em branco, as insinuações, os subentendidos, que estão presentes no texto literário e são fundamentais porque criam espaço para o leitor estabelecer sentidos e se constituir como leitor.

Com a análise de diversos livros de literatura infantil pretende-se dotar os professores "de um arsenal que lhes possibilite entender melhor os livros para crianças e compreender seu próprio entendimento e o das crianças-leitoras." (HUNT, 2010, p. 39). Assim, objetiva-se que produzam sentido sobre o que leem, conheçam as características de algumas obras e de seu potencial para instigarem seus alunos a se engajarem numa experiência de comunicação estética.

A opção por analisar neste artigo algumas das obras que impactam os estudantes que cursam a disciplina "Metodologia do Ensino da Literatura Infantil" se justifica a partir das reflexões de Lajolo (2009, p. 108), ao esclarecer que

[...] se projeta, de cada texto, uma rede quase infinita de relações: as relações de cada texto com a história de seu autor, com o momento de sua produção, com o gênero em que é escrito, com o estágio da língua no momento de sua composição, com o leitor pretendido, com a situação na qual ocorre aquela leitura, com as expectativas daquele leitor etc. $\mathrm{O}$ contexto de um texto é, pois, um emaranhado de fios que se tecem e se soltam, amarrando-se e desamarrando-se uns nos outros.

Cientes da limitação das análises das obras que serão apresentadas a seguir (Obax, Pra saber voar, $O$ monstro monstruoso da caverna cavernosa, $O$ Grúfalo), ressaltamos que elas representam apenas um fio desse emaranhado contexto dos textos, mas significam um convite inicial ao pedagogo/professor para tecer em conjunto e ao infinito.

A africanidade é um tema que vem ganhando espaço nos debates e não poderia ser diferente no curso de Pedagogia. Nesse contexto, fazem sucesso entre os estudantes as obras Obax, de André Neves, e Pra saber voar, de Ana Terra. Nenhuma delas é explícita sobre o fato de que as histórias se passam na África, mas há inúmeras referências que podem levar o leitor a estabelecer essa relação. Por exemplo, Obax é uma criança negra que vive suas aventuras pelas savanas; a ilustração explora os padrões de tecidos muito coloridos com que se vestem as personagens e que sugerem imagens de plantas das savanas; as mulheres adultas usam turbantes; as crianças têm penteados afros com trança raiz e nagô; a arquitetura é bem marcante com suas casas cilíndricas e pintadas com motivos geométricos. 
Encanta aos estudantes o fato dessas obras não terem como tema a africanidade, mas com potencial para que esse aspecto seja trazido nas entrelinhas pelo leitor, atento às ilustrações. Obax trata da imaginação da menina e do descrédito de adultos e crianças (com exceção de sua mãe) sobre as narrativas de suas aventuras, como a chuva de flores e os animais que ela supostamente vira. Obax foge ao ter seus relatos desacreditados. A partir daí começam as aventuras da garota, montada no elefante Nafisa, com o qual ela dá a volta ao mundo (da imaginação), sem encontrar sua chuva de flores e, na volta, sem novamente convencer as pessoas de suas aventuras. O elefante era uma pedra que "plantada" por ela vira um baobá, cujo tronco tem as mesmas texturas da pele de Nafisa. É do baobá que "chovem" as flores e em seus galhos dormem as crianças para corresponderem ao que se fala finalmente sobre os sonhos propiciados pela árvore.

Em Pra saber voar, a ilustração que antecede o texto escrito já traduz e apresenta o sentido geral da narrativa, como saberemos: um rinoceronte (corpulento e maciço) está deitado à sombra de uma pequena árvore, enquanto um pássaro (delgado e leve) pousa em suas costas. A cor amarelada do fundo, que será dominante em quase todo o livro, lembra a das savanas. O texto apresenta o rinoceronte como protagonista e alude à cena retratada, embora não se refira à ave, corroborando a hipótese de que a imagem prefigura, como metáfora visual, o sentido da narrativa, além de ser também um dado "naturalista".

Entretanto o texto não corresponde a uma mera descrição da imagem visual, mas já apresenta o que será uma das características do livro: sua maior complexidade, devida a seu caráter poético-reflexivo, em frases como: "Ver um rinoceronte exibindo solidão já não exige tamanha raridade.” (p. s/n). Com isso, o livro correria o risco de apresentar uma maior abstração, não fossem as ilustrações e algumas metáforas, ou seja, imagens verbais, que ajudam a concretizar a narrativa, embora possam causar um saudável estranhamento.

Apesar de escrito em prosa, o texto constrói-se com recursos poéticos complexos: metáforas, como em "a pele arrepia sentimentos", "lamber caminho", "dormente de coragem"; construções pouco comuns como "sem cuidar de escolha"; "e todo o corpo [...] desiste de pesar"; além dos recursos poéticos sonoros das aliterações e assonâncias, como na repetição de $d$, principalmente, em "e todo o corpo, dormente de coragem, desiste de pesar e se despede do chão" (p. s/n). A musicalidade das palavras e suas imagens inusitadas compensam de certa forma a relativa abstração do texto, pois, junto às ilustrações coloridas, são capazes de "concretizá-lo". Há muitas imagens verbais, que dialogam com as ilustrações: "E logo veste nuvens" (p. 16) é ilustrada com a figura do rinoceronte de chifres e rabo perfurando nuvens, como se essas fossem chapéu e adereço. 
Entretanto paratextos que acompanham o livro contribuem para a construção dos significados da narrativa poética, tanto na apresentação da obra na quarta capa, quanto na autoapresentação feita pela autora, ao final dos textos literários e das ilustrações: "Eu me chamo Ana Terra, mas nem por causa do meu nome deixo de desejar o céu. [...] Voo com ideias, com os olhos. Voo com os sonhos. Com palavras e cores!” (p. s/n). Tal posfácio explicita e reforça a mensagem da fábula, como um discurso paralelo e complementar aos das palavras poéticas e imagens visuais coloridas - sempre mais importantes e efetivas.

Um outro tema que exerce grande atração são os monstros, e sobre ele analisou-se $O$ monstro monstruoso da caverna cavernosa, de Rosana Rios e ilustração de André Neves (o mesmo ilustrador e autor de Obax) e O Grúfalo, de Julia Donaldson, traduzido do inglês por Gilda de Aquino, com ilustração de Axel Scheffler. O título e a ilustração da capa de $O$ monstro monstruoso da caverna cavernosa induzem o leitor a imaginar se tratar de uma história sangrenta, pois as letras do título parecem grafadas com sangue e saindo de uma enorme caverna um horroroso e enorme monstro. No entanto isso não passa de uma provocação inicial. O monstro, embora muito grande e com muitos dentes, é bonachão, veste bermuda e chinelo e só gosta mesmo é de tomar sorvete. Mas, um belo dia, é tirado de seu sossego ao receber uma carta da Associação Associada dos Monstros Monstruosos, advertindo-o de que ele não tem cumprido com as suas obrigações. Eles o ameaçam de expulsão da associação se não devorar logo uma princesa.

A humanização do monstro é muito divertida, como no trecho:

Monstro Monstruoso não queria ser expulso da Associação. Toda a sua família Monstruosa era sócia! Mamãe Monstra não ia gostar nem um pouco se viesse a saber... E ela ficaria sabendo! Os monstros, além de serem... bem... monstruosos e de gostarem muito de assustar as pessoas, adoram uma fofoca. (p. 11)

Ele detestava comer princesas, mas teve a ideia de parecer interessado em encontrar uma colocando um anúncio no jornal. Ele tinha certeza de que não apareceriam candidatas e que ninguém o acusaria de não tentar. Com isso, "ele continuaria feliz da vida em sua caverna, tomando sorvetes." (p. 11). Mas a Associação, ao ler o anúncio, providenciou que lhe fosse entregue um embrulho contendo uma das princesas que tinham em estoque. Ao abrir o embrulho a princesa grita desesperada. Para acalmá-la, ele esclarece que não vai devorá-la. Acabam descobrindo que são seres incomuns, ele um monstro 
bonachão e ela uma princesa que acha o castelo e os passatempos de princesa uma chatice. Resolvem morar juntos e se tornam grandes amigos que fazem deliciosas receitas de sorvete.

Mas o sossego acaba quando a Associação dos Heróis Heroicos envia um príncipe para salvar a princesa confinada na caverna. Assim, surge mais um anti-herói, pois é um príncipe míope, que revela não ter nenhum jeito para herói e ter sido obrigado pela sua associação a ir salvar a princesa. Cabe à personagem feminina dar uma solução à situação. Ela propõe morarem juntos e montarem uma sorveteria, que acaba fazendo um grande sucesso. Na penúltima página o narrador conversa com o leitor:

Bem, agora esta história está chegando ao fim.Se fosse uma história de amor, e não uma história de monstros, eu arrumariaum namoro e um casamento entre o Príncipe e a Princesa. Mas isso você mesmo pode imaginar, sequiser.

Felizes para sempre? (p. 29).

E, na última página, o leitor é surpreendido pelo final, quando são relatadas as dificuldades cotidianas da convivência dos três, mas em que "eles são felizes, sim. Pois fazem o que realmente gostam de fazer: SORVETES!" (p. 30). Essa resolução prosaica reforça o caráter paródico da narrativa, ou seja, sua apropriação humorística de alguns tipos de textos tradicionais para crianças, principalmente os dos contos de fadas, mesclando-se nela o arcaico e o moderno, o fantástico e o corriqueiro. Isso não apenas quanto à fábula e seu enredo, mas quanto à linguagem que os constitui. Dois recursos principais podem ser constatados nesse aspecto da linguagem que recorre a clichês para questioná-los e desconstruí-los: o uso proposital da redundância, com intento irônico, que já está no título do livro e percorre toda a narrativa, como em "Associação Heroica dos Heróis", "Princesa Principesca", "Príncipe Principiante" etc.; e o recurso ao paradoxo, como em: "Era um monstro dos legítimos: tinha dois narizes, quatro braços, seis orelhas, duzentos e dezenove dentes. E era tão simpático!" (p. 4). Com efeitos cômicos como esse, acentua-se a ambiguidade do texto e seu caráter dubitativo ("Felizes para sempre?") no questionamento de clichês e estereótipos, embora esses sejam utilizados por permitirem o reconhecimento dado pelas expectativas quanto aos gêneros literários tradicionais, com suas princesas ameaçadas por dragões e salvas pelos príncipes. Junto a essa divertida quebra de expectativas de gêneros (literários) e seus clichês, há também o questionamento de estereótipos de gêneros, como construções sociais 
e culturais de papéis, o que é perceptível na história pela inadequação de seus personagens aos padrões de monstruosidade (do monstro), heroísmo (do príncipe) e passividade (da princesa). Sobre questão correlata, afirma Jauss, numa de suas teses sobre a estética da recepção:

A análise da experiência literária escapará ao psicologismo que a ameaça se, para descrever a recepção e os efeitos de uma obra, reconstituir o sistema objetivável de referências que compõe o horizonte de expectativa, o qual resulta, para cada obra, no momento de seu aparecimento, de três fatores: a compreensão prévia do gênero, a forma e temática de obras anteriormente conhecidas e a oposição entre linguagem poética e linguagem prática (JAUSS, 1993, p. 65).

Em $O$ Grúfalo, narrativa traduzida do inglês, o menor dos animais da floresta, o rato, é a refeição predileta de vários bichos: a raposa, a coruja e a cobra. Cada um deles tenta enganar o rato convidando-o, com brandura, para almoçar. Mas o rato afirma que não pode aceitar, pois já marcou para almoçar com o Grúfalo. Ao ser interpelado sobre o que é um Grúfalo, ele descreve características terríveis sobre suas presas, garras, dentes, patas peludas, verrugas, olhos alaranjados, espinhos. Informa que eles vão se encontrar bem naquele lugar e que o prato preferido dele é cada um daqueles animais, que fogem, sem mais dizer. E o ratinho, a cada vez, fica se perguntando: "Será que não sabe que Grúfalo não existe?" Mas para surpresa do rato, ele se depara como monstro e, para se safar de ser devorado, usa de sua esperteza afirmando ser a mais perigosa dentre as criaturas da floresta. Ele pede que o Grúfalo o siga para que demonstre isso. Quando encontram cada um daqueles animais que queriam devorar o rato, esses ficam apavorados diante do monstro e fogem. Com isso o ratinho "demonstra" que todos tinham medo dele e ameaça comer seu prato predileto: Grúfalo ensopado. Enfim, o monstro foge e tudo se acalma na floresta, onde o ratinho achou uma deliciosa noz para comer.

Como a narrativa anterior, $O$ Grúfalo também lança mão de um gênero literário facilmente reconhecível pelas crianças, nesse caso, a fábula. E de um tipo bastante conhecido, que é o dos bichos mais fracos, os quais, por isso, precisam ser espertos para sobreviver. Apesar de aqui o texto ser mais curto, não haver ilustrações estilizadas, nem a ironia paródica como na relação intertextual detectável na história anterior, temos em $O$ Grúfalo algo que seria complexo, mas é tratado de forma simples: a metalinguagem, pois junto aos eventos narrativos trata-se dos poderes da imaginação, da fabulação e da própria linguagem, pois 
é a partir dela que o ratinho consegue sobreviver em meio a tantos perigos, ao atravessar a floresta. Afinal, o monstro passa a existir ao ser inventado pelo bichinho, para esse se proteger. Ou seja, ao ser criado o nome "Grúfalo", e ao ser descrito para os animais perigosos que lhe perguntam "o que é um Grúfalo?", é que esse se torna "real", possibilitando ao rato neutralizar esses perigos, inclusive o de que sua criatura se volte contra ele mesmo.

A própria linguagem da narrativa é ritmada e apresenta rimas, o que a torna mais adequada à oralidade, à leitura em voz alta, sendo as ilustrações, embora atraentes, menos estilizadas do que as dos livros anteriormente analisados, apresentando caráter mais restritivo e descritivo, por exemplo, ao se prenderem às descrições do monstro feitas pelo ratinho, em seus detalhes. Algo interessante nos quatro livros, e que tem se tornado comum na literatura para crianças, é o fato de muitas de suas páginas trazerem apenas ilustrações, como um modo de atiçar a curiosidade e fomentar a imaginação dos leitores.

\section{Considerações finais}

Desde que as técnicas de impressão colorida tornaram mais atraentes os livros para crianças, a partir do século XIX, sua importância tem se acentuado, constatando-se, inclusive, que, em duas das obras aqui consideradas, as autorias dos textos e das ilustrações são das mesmas pessoas, como já adiantamos, criando-se tudo de forma mais orgânica. E nos livros analisados avulta a importância das ilustrações e cores que ocupam cada página inteiramente e em que os textos curtos são inscritos, sendo frequente haver páginas sem textos e mesmo sem ilustrações, como, por exemplo, as páginas iniciais, finais e nas contracapas de Pra saber voar que, numa alusão evidente à cor do céu, são plenas de azul.

Conforme já escrevia pioneiramente Walter Benjamin, em 1924, no texto "Livros infantis velhos e esquecidos":

Liberta de toda responsabilidade, a fantasia pura se deleita nesses jogos de cores. Pois os livros infantis não servem para introduzir seus leitores, de maneira imediata, no mundo dos objetos, animais e seres humanos, para introduzi-los na chamada vida. Só aos poucos o seu sentido vai se constituindo no exterior, e isso apenas na medida em que se estabelece uma correspondência adequada com o seu interior. A interioridade dessa contemplação reside na cor, e em seu meio desenrola-se a vida sonhadora que as coisas levam no espírito das crianças. Elas aprendem no colorido. 
Pois na cor, como em nenhum outro lugar, a contemplação sensual e não nostálgica está em casa (BENJAMIN, 2009, p. 61-62).

Apesar de os paratextos, com depoimentos dos autores e as apresentações dos livros trazerem informações sobre seus significados, pedagogicamente úteis, é pela "interioridade dessa contemplação" que "desenrola-se a vida sonhadora que as coisas levam no espírito das crianças", as quais "aprendem no colorido", para retomar as belas e certeiras reflexões de Benjamin. Mesmo que esse não seja citado nenhuma vez pelo pesquisador Peter Hunt (2010), ele apresenta posição semelhante à do filósofo, crítico literário e colecionador de antigos livros infantis, quanto à sensualidade da relação entre leitor e livro, na acepção de que este apela também para os sentidos físicos do leitor, contribuindo decisivamente para a construção de significados de uma obra literária. Por tudo isso, a disciplina "Metodologia do ensino da literatura infantil", com seu objetivo de formar professores para atuar com crianças, deve também voltar sua atenção para o suporte livro.

O livro como suporte não é normalmente considerado importante, exceto no caso de artigos de colecionador, do trabalho de bibliófilos ou de livros ilustrados. [...] A maioria das pessoas (e não só crianças) tem uma relação sensual com os livros; como ele é ao tato, o seu peso na mão, o tamanho, a forma (e, para crianças mais novas, seu gosto): tudo importa (HUNT, 2010, p. 119-120).

Também nesse aspecto, Maria Nikolajeva e Carole Scott notam que, principalmente desde o princípio do século XX, na "relação dinâmica entre palavra e imagem", há "a criação de impacto afetivo tanto pelo uso de palavras como pelo design da imagem, incluindo estilo e cor" (NIKOLAJEVA; SCOTT, 2011, p. 327). Mesmo que se perceba em muitos livros a preponderância do literário e da arte visual em sua valorização da imaginação e da fantasia mais soltas, "de impacto afetivo", é notável que elas ainda reforcem o caráter referencial das narrativas literária e visual, como se fosse necessário colocar algum limite aos sobrevoos e viagens imaginativas. Não por acaso, no âmbito dos paratextos e peritextos é que se apresentam essas notas referenciais, como se nelas passasse a residir a moral das fábulas, em nossos tempos de fábulas sem moral, em que esta, se existe, deve ser escamoteada e subsumida em cores e sob outras palavras. Também não é por acaso que as obras em pauta neste artigo sejam fábulas, até 
no sentido tradicional do termo: narrativas alegóricas em que há personagens de animais. Aliás, afora as formiguinhas humanas de Luanda enroladinha, mais prosaicas, os personagens de Obax, além da garotinha, são o elefante (tornado depois em baobá) e o de Pra aprender a voar é o rinoceronte, considerados exóticos; enquanto em $O$ monstro monstruoso da caverna cavernosa e $O$ Grúfalo há também animais, só que fantásticos.

De todo modo, esses personagens fazem parte de alegorias sobre os poderes da imaginação e são também "referencializados" nos paratextos e peritextos que os circunscrevem e limitam, porque os explicam. Aí temos a clássica intenção adulta do "docere delectendo" ("ensinar deleitando"), do poeta latino Ovídio, só que em roupagem atual, não mais com objetivo doutrinário, mas ainda pedagógico, com que se visa a uma educação infantil dos sentidos, para a criação de significados.

\section{REFERÊNCIAS}

AGUIAR, Vera Teixeira de. Leitura literária na escola. In: EVANGELISTA, Aracy et al. A escolarização da leitura literária: o jogo do livro infantil e juvenil. Belo Horizonte: Autêntica, 1999. p. 235-255.

BENJAMIN, Walter. Reflexões sobre a criança, o brinquedo e a educação. Tradução de: Marcus Vinicius Mazzari. São Paulo: Duas Cidades/Editora 34, 2009.

BORDINI, Maria da Glória; AGUIAR, Vera Teixeira de. Literatura. A formação do leitor: alternativas metodológicas. 2. ed. Porto Alegre: Mercado Aberto, 1993.

COSSON, Rildo. A formação do professor de literatura - uma reflexão interessada. In: PINHEIRO, Alexandra Santos; RAMOS, Flávia Brocchetto (org.). Literatura e formação continuada de professores. Desafios da prática educativa. Campinas, São Paulo: Mercado de Letras, 2013. p. 11-26.

DONALDSON, Julia. O Grúfalo. Ilustração de: Axel Scheffler. Tradução de: Gilda Aquino. São Paulo: Brinque-Book, 2002.

GALEANO, Eduardo. O livro dos abraços. Tradução de: Eric Nepomuceno. 7. ed. Porto Alegre: L\&PM, 2000.

HUNT, Peter. Crítica, teoria e literatura infantil. Tradução de: Cid Knipel. São Paulo: Cosac Naify, 2010.

JAUSS, Hans Robert. A literatura como provocação (História da literatura como provocação literária). Tradução de: Teresa Cruz. Lisboa: Vega, 1993. 
JAUSS, Hans Robert. A estética da recepção: colocações gerais. In: LIMA, Luiz Costa. A literatura e o leitor. Textos de estética da recepção. 2. ed. Rio de Janeiro: Paz e Terra, 2002. p. 67-84.

LAJOLO, Marisa. O texto não é pretexto. Será que não é mesmo? In: ZILBERMAN, Regina; ROSING, Tania M. K. (Org.). Escola e leitura. Velha crise, novas alternativas. São Paulo: Global Editora / ALB, 2009. p. 99-112.

NEVES, André. Obax. São Paulo: Brinque-Book, 2010.

NICOLAJEVA, Maria; SCOTT, Carole. Livro ilustrado: palavras e imagens. Trad. Cid Knipel. São Paulo: Cosac Naify, 2011.

RIOS, Rosana. O monstro monstruoso da caverna cavernosa. Ilustração de: André Neves. São Paulo: Universo Livros, 2012.

RODRIGUES, Antonio Cesar Lins. Luanda enroladinha. Ilustração de: Tadeu Costa. São Paulo: Editora Esfera, 2013.

SALDANHA, Diana Maria Leite Lopes; AMARILHA, Marly. Literatura e formação do pedagogo: caminhos que (ainda) não se cruzam. Desenredo. Revista do Programa de Pós-Graduação em Letras da Universidade de Passo Fundo, v. 12, n. 2, p. 376-396, jul./ dez, 2016. Disponível em: <http://seer.upf.br/index.php/rd/article/view/6389>. Acesso em: 15 fev. 2018.

TERRA, Ana. Pra saber voar. Belo Horizonte, MG: Abacatte, 2013.

ZILBERMAN, Regina. Estética da recepção e história da literatura. São Paulo: Ática, 2004.

Texto recebido em 08 de junho de 2018. Texto aprovado em 08 de agosto de 2018. 